\title{
PENGARUH PENAMBAHAN STARTER BAKTERI ASAM LAKTAT PADA PEMBUATAN BEKASAM IKAN SEPAT (Trichogaster trichopterus) TERHADAP MUTU DAN DAYA AWETNYA
}

\author{
Jovita Tri Murtini ${ }^{\star}$, Ernik Yuliana ${ }^{* *}$, Nurjanah $^{* *}$ dan Suyuti Nasran ${ }^{*}$
}

\begin{abstract}
ABSTRAK
Penelitian pengolahan bekasam ikan sepat dengan sumber karbohidrat tape nasi yang ditambah dengan sumber bakteri asam laktat, yaitu cairan asinan kubis dan sawi, telah dilakukan untuk memperbaiki mutu dan daya awetnya. Dalam penelitian ini dicoba 3 perlakuan, yaitu pertama ditambah cairan asinan kubis $125 \mathrm{~mL} / \mathrm{kg}$ ikan; ke dua, cairan asinan sawi 125 $\mathrm{mL} / \mathrm{kg}$ ikan; dan ke tiga, tanpa penambahan sumber bakteri asam laktat sebagai kontrol. Bekasam disimpan pada suhu kamar selama 8 minggu, dan pengamatan dilakukan setiap dua minggu. Hasil penelitian menunjukkan bahwa perlakuan cairan asinan sawi dan kubis berpengaruh nyata terhadap jumlah unit koloni bakteri asam laktat, bakteri aerob, bakteri anaerob, khamir, nilai pH, TVA dan lemak. Kadar asam laktat hanya dipengaruhi oleh lama penyimpanan. Perlakuan cairan asinan sawi maupun asinan kubis dapat mengurangi penurunan bakteri asam laktat, begitu juga dengan bakteri anaerob. Dalam hal ini perlakuan yang paling baik adalah cairan sawi. Selama penyimpanan, semua mikroba mengalami penurunan jumlah. Dari uji organoleptik, produk yang paling disukai oleh panelis adalah bekasam yang mendapat perlakuan cairan asinan sawi. Pada semua perlakuan, produk yang disimpan selama 8 minggu masih diterima.
\end{abstract}

\begin{abstract}
Effects of addition of lactic acid bacteria starter in the processing of spotted gouramy (Trichogaster trichopterus) bekasam on its quality and shelflife. By: Jovita Tri Murtini, Ernik Yuliana, Nurjanah and Suyuti Nasran.
\end{abstract}

An experiment on the processing of bekasam using fermented rice as carbohydrate source and liquids of cabbage and chinese leaf pickles as lactic acid bacteria sources had been conducted to know the product quality and shelflife. Three treatments were investigated i.e. (1) addition of cabbage pikcle liquid (2) chinese leaf pickle liquid and (3) without addition of those liquids as control. The products were then stored at ambient temperature for 8 weeks and were observed for their quality bi-weekly. The results showed that the addition of pickle liquid indicated significant effects on lactic acid bacteria count, aerob and anaerob bacteria counts, yeast counts, pH value, TVA and fat content, while lactic acid content was only influenced by storage treatment. The pickle liquid addition were able to decrease of the number of lactic acid bacteria. Number of all kinds of bacteria including lactic acid bacteria decreased during storage. Organoleptic test resulted that the best treatment was the addition of chinese leaf pickle. All treated products were still accepted by panelis after 8-week storage.

KEYWORDS: Lactic acid bacteria; starter; spotted gouramy.

\section{PENDAHULUAN}

Fermentasi merupakan salah satu cara pengolahan ikan yang cukup penting, dengan cara ini diperoleh produk-produk yang digemari oleh sebagian masyarakat karena flavor dan aromanya yang khas. Pada proses fermentasi ikan bergaram, yang berperan sebagai faktor pengawet bukan hanya garam tetapi juga asam-asam dan senyawa lain yang dihasilkan oleh mikroba yang melakukan fermentasi (Irawadi, 1979). Aktivitas bakteri asam laktat berlawanan dengan bakteri

\footnotetext{
*) Peneliti pada Balai Penelitian Perikanan Laut, Jakarta

**) Staf Pengajar Institut Pertanian Bogor
} 
patogen dan pembusuk, yang menghasilkan asam laktat dan asam cuka yang dapat menurunkan pH untuk menghambat bakteri yang tidak diinginkan. Beberapa penelitian telah dilakukan antara lain pengawetan produk daging dengan starter bakteri asam laktat yang menghasilkan bakteriosin (Leroi et al., 1996). Bakteri asam laktat (Lactobacillus) dari asinan kubis maupun sawi memproduksi asam laktat dalam jumlah besar (Prescott dan Dunn, 1959). L. plantarum menghasilkan asam laktat yang banyak pada akhir proses yang akan mengasamkan produk (Garrega et al., 1996). Asam laktat ini yang dapat mengawetkan ikan karena nilai $\mathrm{pH}$ yang dihasilkan rendah. Fermentasi ikan dengan menggunakan sumber karbohidrat pada umumnya membutuhkan garam dalam jumlah yang rendah dibandingkan dengan fermentasi yang menggunakan ikan dan garam saja. Sumber karbohidrat yang dapat digunakan misalnya nasi, tepung tapioka, beras sangrai dan tape ketan (Adams et al., 1985; Murtini et al., 1991; Murtini, 1992). Di Jepang, penambahan nasi pada pembuatan $I$ shusi (fermented shusi) adalah 40-50\% dari bobot ikan, yang diletakkan pada dasar tempat fermentasi dan juga pada perut ikan (Tanikawa, 1971).

Bakteri asam laktat sebenarnya terdapat dalam tubuh ikan tetapi jumlahnya kecil sehingga untuk memfermentasi karbohidrat harus ditambahkan dari luar. Begitu pula sumber karbohidrat untuk fermentasi juga terbatas dalam tubuh ikan sehingga diperlukan tambahan dari luar.

Pada penelitian ini sumber bakteri asam laktat yang digunakan adalah cairan asinan sawi dan kubis. Kedua jenis asinan sayur ini mudah dibuat dan harga bahan bakunya relatif murah. Baik asinan sawi ataupun asinan kubis, yang dimanfaatkan oleh masyarakat hanya sayurnya, sedangkan cairannya belum dimanfaatkan. Oleh karena itu, pada penelitian ini dicoba untuk memanfaatkan cairan dari asinan sawi dan kubis. Adapun sumber karbohidrat yang digunakan sebagai substrat bakteri asam laktat adalah tape nasi.

Tujuan penelitian ini adalah untuk mem. bandingkan mutu bekasam hasil fermentasi dengan 3 jenis perlakuan, yaitu penambahan starter bakteri asam laktat yang berupa asinan sawi dan asinan kubis, dibandingkan dengan kontrol (tanpa penambahan starter).

\section{BAHAN DAN METODE}

Bahan utama adalah ikan sepat (Trichogaster trichopterus) yang diperoleh dari Kabupaten Ogan Komering Ilir (Sumatera Selatan). Ukuran ikan sepat yang digunakan sebagai berikut: panjang total $14,12 \pm 1,04 \mathrm{~cm}$, tebal $16,42 \pm 1,37$ $\mathrm{mm}$, lebar 42,30 $\pm 3,72 \mathrm{~mm}$ dan bobot 36,0 $\pm 9,32$ gram/ekor. Ikan sepat segar dies dalam peti berinsulasi, kemudian dibawa ke laboratorium di Jakarta sekitar 17 jam.

Bahan pembantu yang digunakan adalah cairan asinan sawi, cairan asinan kubis, tape nasi yang dibuat di laboratorium, gula pasir dan garam dapur.

\section{Penelitian Pendahuluan}

Penelitian pendahuluan yang dilakukan adalah pembuatan asinan sawi dan asinan kubis untuk mendapatkan bakteri asam laktat pada puncak pertumbuhannya, yaitu dengan mengetahui jumlah koloni yang dihasilkan. Selanjutnya mencari volume optimum bakteri asam laktat untuk ditambahkan pada proses pembuatan bekasam. Cara penambahan yang dicoba adalah pengolesan dan pencelupan. Selanjutnya hasil yang terbaik digunakan untuk penelitian utama.

\section{- Cara pembuatan asinan sawi/kubis}

Sawi/kubis dicuci dan ditiriskan selanjutnya dilayukan selama semalam. Kemudian kedua sayuran ini diiris dan diremas selanjutnya dimasukkan ke dalam stoples berisi larutan garam $2,5 \%$ dan gula $1 \%$ sampai sawi/kubis terendam selama empat hari. Cairan asinan yang siap digunakan mempunyai kandungan bakteri asam laktat 9,0 × $10^{7}$ unit koloni/mL untuk asinan sawi dan $5,0 \times 10^{7}$ unit koloni/mL untuk asinan kubis.

\section{- Cara pembuatan tape nasi}

Beras dicuci kemudian ditanak. Nasi yang telah dingin ditaburi ragi tape sebanyak 0,04 $0,05 \%$ dicampur sampai merata dan selanjutnya diperam selama $3-4$ hari.

\section{Penelitian Utama}

Dalam penelitian utama ini dilakukan pembuatan bekasam ikan sepat dengan 3 perlakuan, 
yaitu (1) ditambah cairan asinan kubis sebanyak $125 \mathrm{~mL} / \mathrm{kg}$ ikan, (2) ditambah cairan asinan sawi sebanyak $125 \mathrm{~mL} / \mathrm{kg}$ ikan, dan (3) kontrol (tanpa starter).

Pembuatan bekasam diawali dengan menyiangi (membuang isi perut, kepala dan sisik) ikan sepat, mencuci dan meniriskan, kemudian merendamnya dalam larutan garam $15 \%$. Penggaraman dilakukan selama 48 jam dan ikan diberi pemberat di atasnya agar tidak terapung atau kontak dengan udara. Ikan yang telah digarami kemudian dicuci, ditiriskan dan ditambah dengan starter bakteri asam laktat yang berasal dari asinan sawi/kubis, selanjutnya ditambah sumber karbohidrat, yaitu tape nasi sebanyak $50 \%$ yang sebagian dimasukkan ke dalam perut ikan. Kemudian ikan difermentasikan dalam kotak-kotak plastik selama satu minggu, dilanjutkan dengan penyimpanan selama delapan minggu pada suhu kamar. Setiap kotak berisi ikan sepat sekitar $1 \mathrm{~kg}$ dan ditutup rapat.

Pengamatan mutu bekasam dilakukan setiap 2 minggu, dimulai sejak selesai fermentasi 1 minggu. Parameter yang digunakan antara lain adalah pengamatan kimia, yaitu: $\mathrm{pH}$ (diukur dengan $\mathrm{pH}$ meter), kadar asam laktat (AOAC, 1984), jumlah asam yang menguap (TVA) dengan cara destilasi, kadar air (oven $\pm 105^{\circ} \mathrm{C}$ ), protein (Kjeldahl), lemak (Soxhlet), abu (muffel furnace dengan suhu $\pm 550^{\circ} \mathrm{C}$ ), dan kadar nitrogen bukan protein( NPN) dengan cara destilasi. Di samping itu, dilakukan pengamatan mikrobiologi yang terdiri atas jumlah bakteri aerob, jumlah bakteri anaerob, bakteri asam laktat dan khamir. Semua pengawetan menggunakan metode tuang dengan media nutrient agar (NA) untuk jumlah bakteri, MRS agar untuk bakteri asam laktat, dan malt ekstrak agar untuk khamir. Pengamatan organoleptik meliputi: rupa, warna, bau, tekstur dan rasa dilakukan dengan menggunakan skala hedonik 9, dengan nilai 9 untuk mutu terbaik. Rancangan percobaan yang digunakan dalam penelitian ini adalah Rancangan Acak Lengkap Pecah Petak dengan 2 ulangan. Untuk penghitungan uji organoleptik dipakai uji nonparametrik Kruskal-Wallis.

\section{HASIL DAN PEMBAHASAN}

\section{Penelitian Pendahuluan}

Dari penelitian pendahuluan diketahui bahwa total bakteri asam laktat pada cairan asinan sawi hasil fermentasi selama 4 hari adalah $9,0 \times 10^{7}$

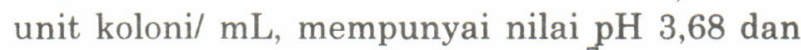
pada asinan kubis adalah 5,0 x $10^{7}$ unit koloni/ $\mathrm{mL}$ dengan $\mathrm{pH}$ 3,77. Di samping itu, bekasam yang diperoleh dengan cara pengolesan mempunyai nilai total bakteri asam laktat dan kadar asam laktat yang lebih tinggi dibandingkan dengan cara pencelupan. Diduga dengan pengolesan, cairan asinan lebih banyak meresap ke dalam tubuh ikan. Hasil analisis kimia dan mikrobiologi ikan sepat dicantumkan pada Tabel 1. Berdasarkan hasil ini maka pada penelitian utama, penambahan starter bakteri asam laktat dilakukan dengan cara pengolesan.

Tabel 1. Hasil analisis percobaan pendahuluan bekasam ikan sepat setelah fermentasi selama tujuh hari

Table 1. Result of preliminary experiment of spotted gouramy bekasam after 7-day fermentation.

\begin{tabular}{clcc}
\hline $\begin{array}{c}\text { Perlakuan } \\
\text { Treatment }\end{array}$ & $\begin{array}{c}\text { Cara penambahan } \\
\text { Addition method }\end{array}$ & $\begin{array}{c}\text { Bakteri asam laktat } \\
\text { Lactic acid bacteria } \\
\text { (cfu/g) }\end{array}$ & $\begin{array}{c}\text { Kadar asam laktat } \\
\text { Lactic acid content } \\
\text { (\%) }\end{array}$ \\
\hline Asinan kubis & pengolesan (smearing) & $2.43 \times 10^{8}$ & 2.97 \\
Cabbage pickle & pencelupan (dipping) & $2.01 \times 10^{8}$ & 2.88 \\
Asinan sawi & pengolesan (smearing) & $4.76 \times 10^{8}$ & 2.52 \\
Chinese leaf pickle & pencelupan (dipping) & $2.44 \times 10^{8}$ & 2.34 \\
\hline
\end{tabular}




\section{Penelitian Utama}

\section{- Hasil pengamatan mikrobiologi}

Hasil analisis ragam menunjukkan bahwa perlakuan cairan asinan sawi, asinan kubis, dan lama penyimpanan berpengaruh sangat nyata terhadap jumlah bakteri asam laktat pada bekasam. Begitu juga interaksi antara perlakuan cairan asinan sawi dengan lama penyimpanan berpengaruh sangat nyata terhadap jumlah bakteri asam laktat, serta antar perlakuan cairan sawi, kubis dan kontrol berpengaruh nyata. Pola pertumbuhan bakteri asam laktat pada semua perlakuan cenderung menunjukkan pola yang sama, yaitu makin lama penyimpanan, jumlah bakteri makin menurun. Pada penyimpanan minggu ke dua, pertumbuhan bakteri asam laktat pada kontrol menurun drastis, tetapi pada perlakuan cairan asinan sawi dan asinan kubis menurun perlahan-lahan, dan pada perlakuan cairan asinan sawi, mula-mula melalui masa stabil. Penurunan bakteri asam laktat pada kontrol diduga karena sisa substrat yang sedikit dan nilai $\mathrm{pH}$ yang rendah, serta dihasilkannya hidrogen peroksida dan bakteriosin yang dapat menghambat pertumbuhan bakteri asam laktat sendiri. Bakteri asam laktat homofermentatif misalnya $L$. plantarum, banyak diproduksi oleh asinan kubis (Prescott dan Dunn, 1959; Fardiaz, 1985). Pada Gambar 1 juga dapat dilihat bahwa perlakuan cairan asinan sawi mempunyai pengaruh yang lebih baik dibandingkan dengan perlakuan asinan kubis. Penurunan jumlah bakteri pada perlakuan $\mathrm{C}$ (asinan sawi) tidak secepat pada perlakuan B (asinan kubis). Ini berarti bahwa perlakuan cairan asinan sawi lebih dapat mempertahankan sintasan bakteri asam laktat, dan lebih menguntungkan bila ditambahkan pada bekasam.

Analisis ragam bakteri anaerob menunjukkan bahwa jumlah koloni dipengaruhi oleh perlakuan cairan asinan sawi, asinan kubis, lama penyimpanan, dan interaksi antara kedua perlakuan dengan lama penyimpanan. Pertumbuhan bakteri anaerob pada kontrol adalah stabil dari minggu ke nol sampai minggu ke enam, kemudian turun secara cepat sampai minggu ke delapan (Gambar 2).

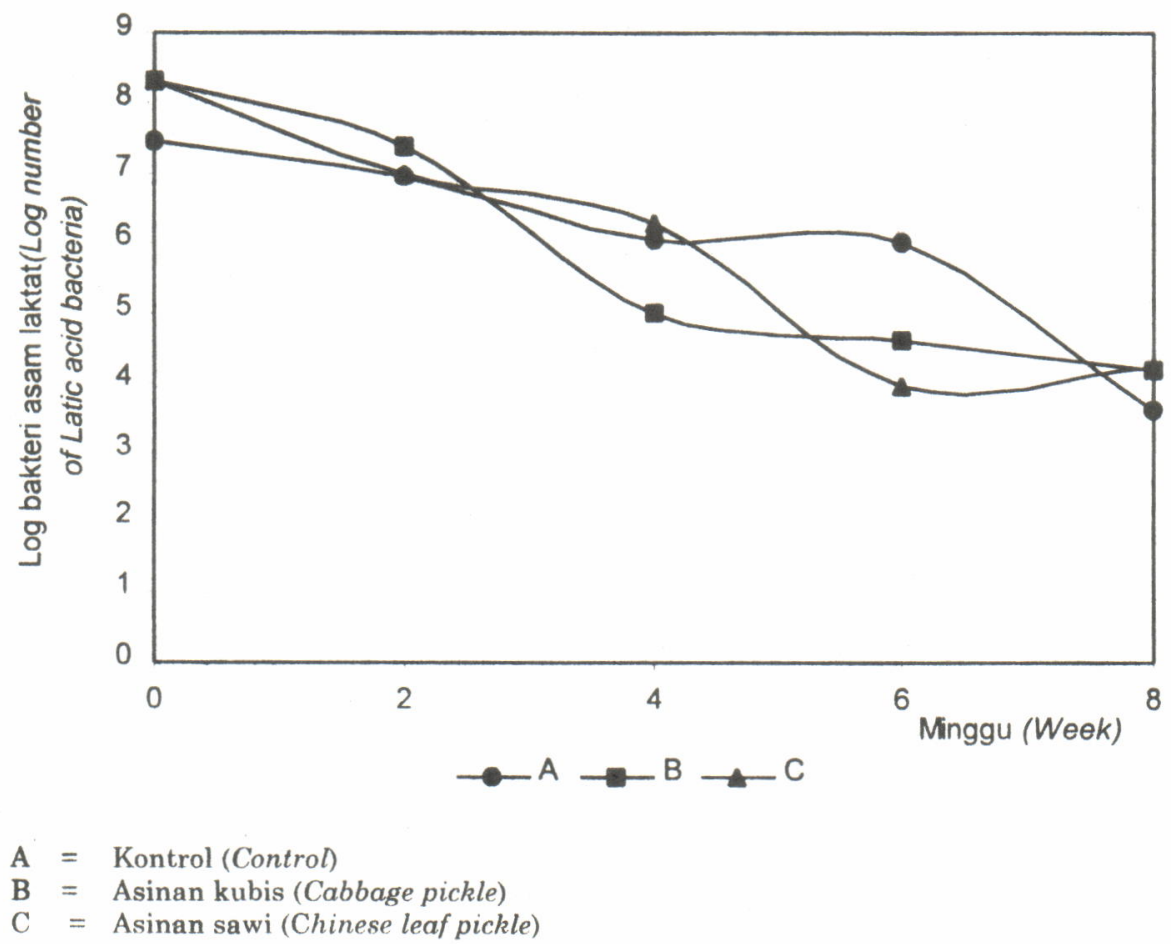

Gambar 1. Pertumbuhan bakteri asam laktat pada bekasam ikan sepat selama penyimpanan.

Figure 1. Growth of lactic acid bacteria on spotted gouramy bekasam during storage. 


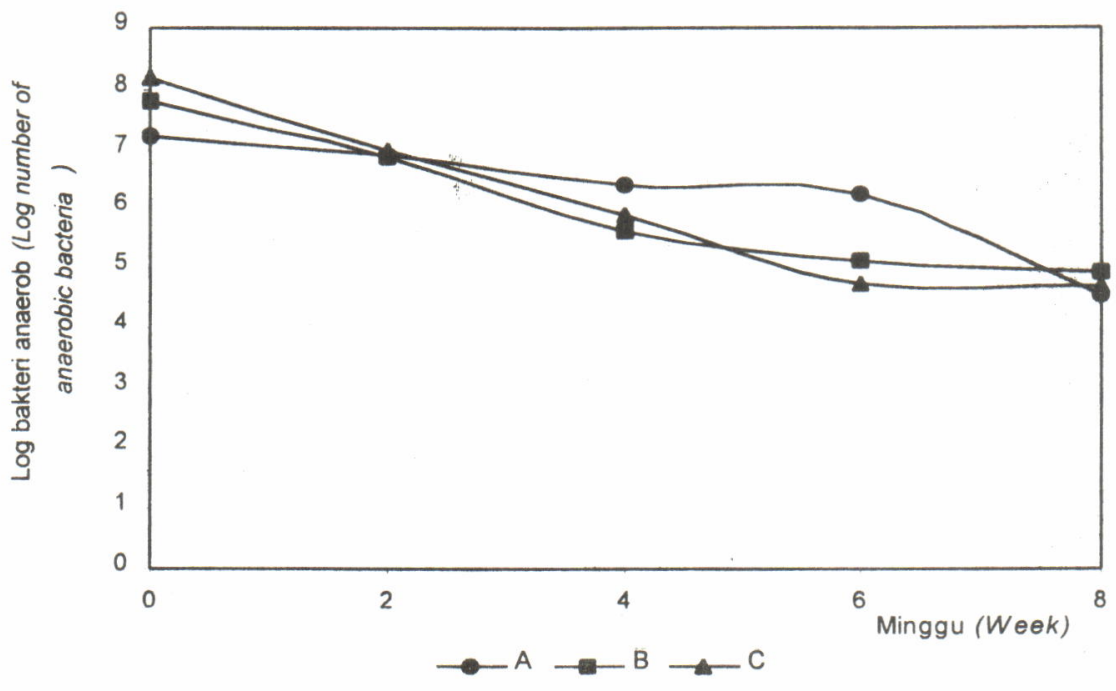

$\mathrm{A}=$ Kontrol (Control)
$\mathrm{B}=$ Asinan kubis (Cabbage pickle)
$\mathrm{C}=$ Asinan sawi (Chinese leaf pickle)

Gambar 2. Pola pertumbuhan bakteri anaerob pada bekasam ikan sepat selama penyimpanan.

Figure 2. Anaerobic bacteria development on spotted gouramy bekasam during storage.

Pada perlakuan cairan asinan sawi, bakteri anaerob menurun dengan cepat sampai minggu ke enam kemudian stabil sampai minggu ke delapan. Kalau dilihat dari jumlahnya selama penyimpanan berkisar antara $1,0 \times 10^{6}$ hingga $2,0 \times 10^{8}$ unit koloni/g, jumlah ini hampir sama dengan jumlah bakteri asam laktat. Maka dapat diartikan bahwa hampir semua bakteri anaerob yang tumbuh pada bekasam adalah penghasil asam laktat yaitu bakteri asam laktat. Pertumbuhan bakteri ini akan terhenti sama sekali pada konsentrasi garam 10\% dan $\mathrm{pH}$ 4-6 (Blood, 1975). Hal ini terbukti pada pertumbuhan yang ditujukkan pada Gambar 2, bahwa bakteri anaerob tidak mengalami pertumbuhan sama sekali, karena $\mathrm{pH}$ bekasam selama penyimpanan berkisar antara 4,3-4,6.

Dapat dilihat juga asinan kubis mempunyai pengaruh yang hampir sama dengan cairan asinan sawi, karena pola penurunan bakteri anaerob hampir sama. Kedua perlakuan yang diberikan pada bekasam tidak mempengaruhi jumlah unit koloni bakteri aerob. Lama penyimpanan, interaksi antara cairan asinan sawi dengan lama penyimpanan, dan interaksi cairan kubis dengan lama penyimpanan berpengaruh nyata terhadap jumlah bakteri ini. Gambar 3 menunjukkan bahwa pertumbuhan bakteri aerob mempunyai kesamaan pola antara masingmasing perlakuan, menurun secara linier dari minggu ke-0 sampai minggu ke delapan.

Bakteri asam laktat dapat mengakibatkan lingkungan yang kurang baik bagi mikroba lain, karena dihasilkannya hidrogen peroksida, bakteriosin dan penurunan $\mathrm{pH}$ medium (Schoder et al. dalam Irawadi, 1979). Hal ini sangat menguntungkan, mengingat bakteri pembusuk termasuk ke dalam kelompok bakteri aerob yang mungkin berperan dalam proses pembusukan bekasam. Dengan adanya penurunan bakteri aerob akibat turunnya $\mathrm{pH}$ medium dan adanya bakteriosin, maka selama penyimpanan tidak terjadi proses pembusukan bekasam.

Karena sumber karbohidrat yang digunakan pada penelitian ini adalah tape nasi yang dimaksudkan untuk memberikan aroma yang segar (aroma alkohol) pada bekasam yang dihasilkan, maka penghitungan koloni khamir perlu dilakukan untuk mengetahui pertumbuhan khamir yang berasal dari tape pada proses fermentasi bekasam. Khamir yang berasal dari tape nasi masih mengalami pertumbuhan setelah ditambahkan pada bekasam. Analisis ragam menunjukkan bahwa jumlah koloni khamir dipe- 
Murtini, J.T.; Yuliana, E.; Nurjanah; dan Nasran, S.

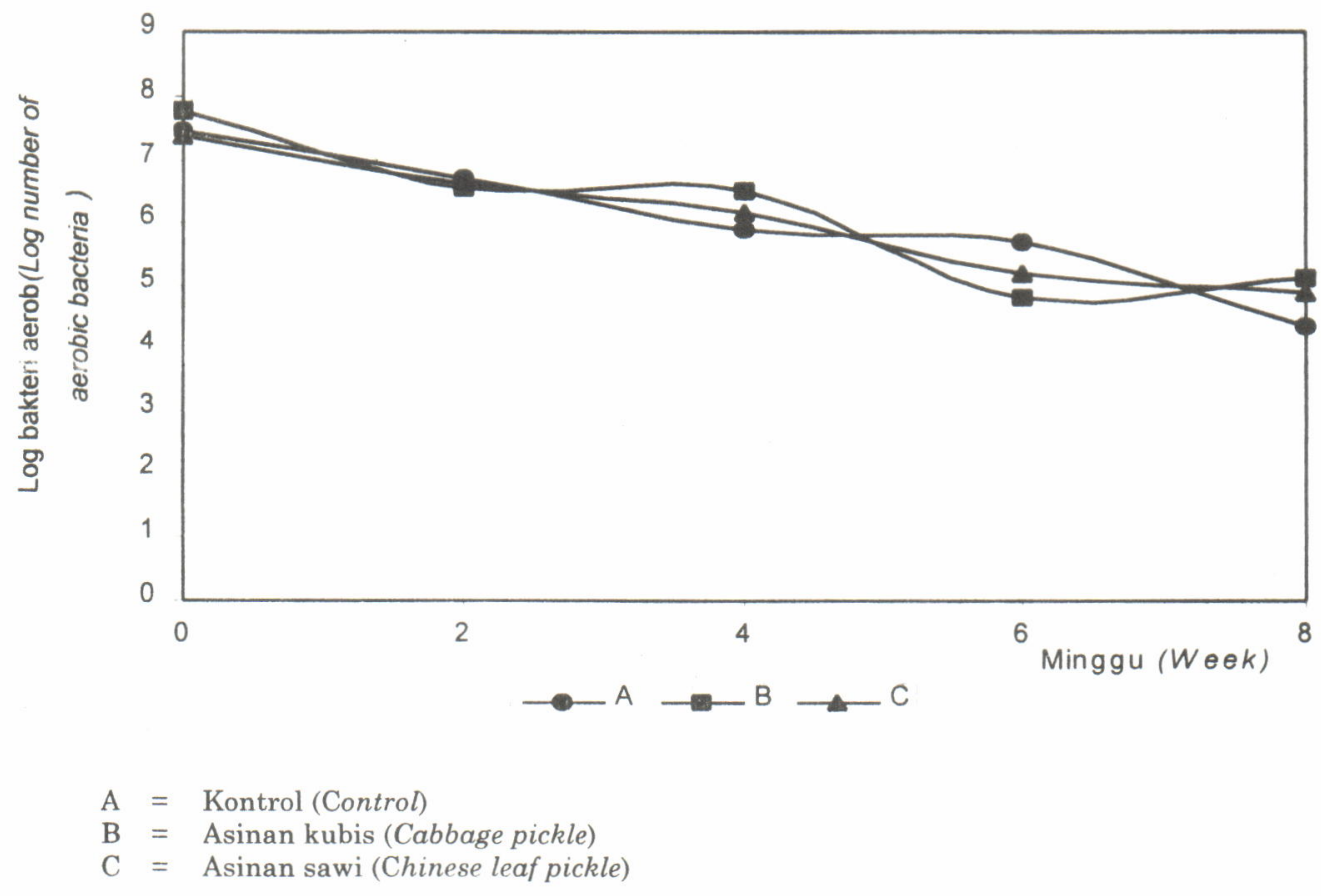

Gambar 3. Pola pertumbuhan bakteri aerob pada bekasam ikan sepat rawa selama penyimpanan. Figure 3. Aerobic bacteria development on spotted gourami bekasam during storage.

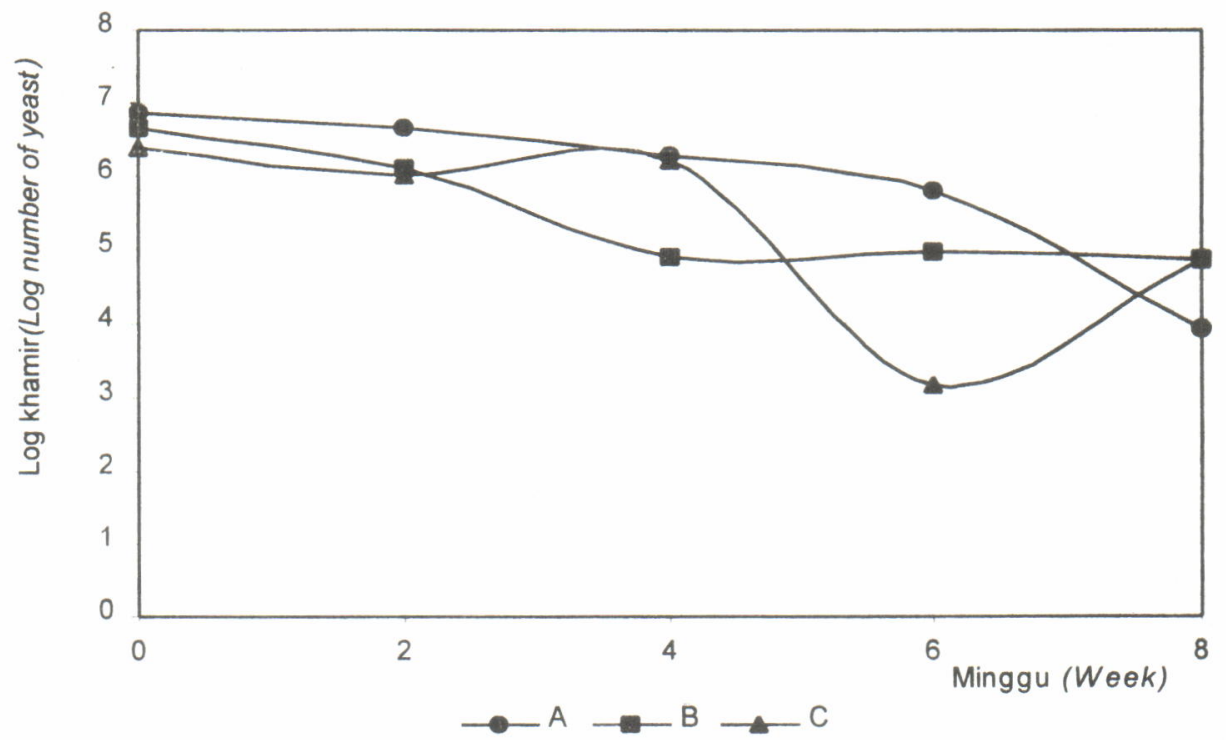
$\mathrm{A}=$ Kontrol (Control)
$\mathrm{B}=$ Asinan kubis (Cabbage pikcle)
$\mathrm{C}=$ Asinan sawi (Chinese leaf pickle)

Gambar 4. Pola pertumbuhan khamir pada bekasam ikan sepat rawa selama penyimpanan. Figure 4. Yeast development on spotted gourami bekasam during storage. 
ngaruhi oleh perlakuan cairan asinan sawi, lama penyimpanan, dan interaksinya. Gambar 4 menunjukkan bahwa pola pertumbuhan khamir pada kontrol berbeda dengan pertumbuhan khamir pada kedua perlakuan yang lain. Pada penyimpanan minggu ke-0 sampai minggu ke empat, jumlahnya cenderung naik, kemudian turun sampai minggu ke delapan. Jumlah khamir pada kedua perlakuan asinan sawi dan asinan kubis mempunyai pola yang sama, yaitu cenderung menurun sampai minggu ke delapan, kecuali pada perlakuan cairan asinan kubis (minggu ke enam sampai ke delapan) di mana jumlah khamirnya stabil. Pada kontrol pertumbuhan khamir mengalami sedikit kenaikan pada minggu ke dua dan empat sedangkan bakteri asam laktat mengalami penurunan. Kompetisi antara khamir dan bakteri asam laktat dalam suatu bahan pangan saling menghambat (Wood dan Hodge, 1985).

\section{- Hasil pengamatan kimiawi}

Hasil analisis ragam menunjukkan bahwa kadar air bekasam tidak dipengaruhi oleh semua perlakuan. Bila dibandingkan dengan kadar air ikan sepat segar, yaitu $78,12 \%$ bobot basah, maka kadar air bekasam lebih rendah. Hal ini disebabkan oleh sifat garam yang higroskopis mampu menarik air keluar dari jaringan daging. Keuntungan dari penggunaan garam adalah terseleksinya bakteri yang hidup pada bekasam. Bakteri pembusuk yang tidak tahan dengan suasana garam akan mati, sehingga bekasam dapat awet selama penyimpanan. Kandungan abu setelah menjadi bekasam meningkat, hal ini disebabkan karena dalam proses fermentasi digunakan garam. Begitu juga kadar protein sedikit menurun karena ada komponen yang meningkat. Tabel 2 menunjukkan hasil analisis proksimat dari bekasam pada awal penyimpanan.

Tabel 2 . Komposisi kimia ikan sepat segar dan bekasam selama penyimpanan.

Table2. Chemical composition of fresh spotted gouramy and bekasam during storage.

\begin{tabular}{lccccc}
\hline \multicolumn{1}{c}{$\begin{array}{c}\text { Perlakuan } \\
\text { Treatment }\end{array}$} & $\begin{array}{c}\text { Peyimpanan } \\
\text { Storage } \\
\text { (minggu/week) }\end{array}$ & $\begin{array}{c}\text { Kadar air } \\
\text { Moisture } \\
\text { (\%wb) }\end{array}$ & $\begin{array}{c}\text { Abu } \\
\text { Ash } \\
\text { (\%db) }\end{array}$ & $\begin{array}{c}\text { Protein } \\
\text { (\%db) }\end{array}$ & $\begin{array}{c}\text { Lemak } \\
\text { Fat } \\
\text { (\%db) }\end{array}$ \\
\hline $\begin{array}{l}\text { Ikan sepat segar } \\
\text { Fresh spotted gouramy }\end{array}$ & - & 78.12 & & & \\
Bekasam tanpa asinan & 0 & 72.37 & 16.65 & 53.53 & 18.95 \\
Bekasam without pickle & 2 & 73.83 & & 59.80 & \\
& 4 & 74.19 & & 53.16 & \\
& 6 & 69.89 & & 48.56 & \\
Bekasam + asinan kubis & 8 & 72.01 & & 54.95 & \\
Bekasam + cabbage pickle & 0 & 72.63 & 20.64 & 56.56 & \\
& 2 & 72.71 & & 58.41 & \\
& 4 & 71.96 & & 45.36 & \\
Bekasam + asinan sawi & 6 & 71.64 & & 44.71 & \\
Bekasam + chinese leaf & 8 & 73.48 & & 43.36 & \\
pickle & 0 & 73.67 & 17.70 & 54.54 & \\
& 2 & 72.24 & & 60.99 & \\
& 4 & 71.13 & & 48.18 & \\
& 6 & 71.98 & & 51.14 & \\
\end{tabular}


Murtini, J.T.; Yuliana, E.; Nurjanah; dan Nasran, S.

Asam laktat yang dihasilkan oleh bakteri asam laktat berpengaruh terhadap penurunan $\mathrm{pH}$ medium. Penurunan $\mathrm{pH}$ medium ini sangat penting pada proses pembuatan bekasam, karena dapat menyeleksi bakteri yang tumbuh. Gambar 5 menunjukkan bahwa nilai $\mathrm{pH}$ selama penyim. panan sedikit meningkat dari 4,34 menjadi 4,50. Analisis ragam menunjukkan bahwa $\mathrm{pH}$ dipengaruhi oleh perlakuan dan tama penyimpanan, tetapi tidak dipengaruhi oleh interaksi antara keduanya. Sedangkan kadar asam laktat sama sekali tidak dipengaruhi oleh perlakuan, tetapi hanya dipengaruhi oleh lama penyimpanan. Gambar 6 menunjukkan bahwa semakin lama waktu penyimpanan, keasaman bekasam semakin berkurang karena produksi asam laktat semakin menurun dan timbulnya basa-basa yang dapat menetralkan asam-asam tersebut.

Pengukuran terhadap asam menguap (TVA) berguna untuk mengetahui komponen flavor yang mudah menguap dari produk fermentasi. Asam menguap pada produk fermentasi berisi kompo- nen beraroma, yang menentukan bau suatu bahan. Nilai TVA ditentukan oleh kandungan asam asetat, formiat, dan $\mathrm{CO}_{2}$. Analisis ragam menunjukkan bahwa selama penyimpanan terutama pada enam minggu pertama terjadi peningkatan TVA walaupun perlakuan cairan asinan sawi dan asinan kubis tidak berpengaruh nyata. Hal ini sesuai dengan hasil penelitian Nurwantoro (1991) bahwa nilai TVA produk fermentasi meningkat dengan lamanya waktu penyimpanan. Nilai TVA juga dipengaruhi oleh interaksi antara perlakuan dengan lamanya penyimpanan. Hasil analisis TVA dapat dilihat pada Gambar 7. Pada perlakuan kontrol, nilai TVA stabil selama penyimpanan meningkat pada minggu ke tiga lalu turun, tetapi pada perlakuan cairan asinan sawi dan asinan kubis terjadi peningkatan sampai minggu ke enam kemudian baru turun. Hal ini disebabkan karena cairan asinan sawi dan kubis yang semula dihasilkan oleh fermentasi telah mengandung banyak jenis asam.

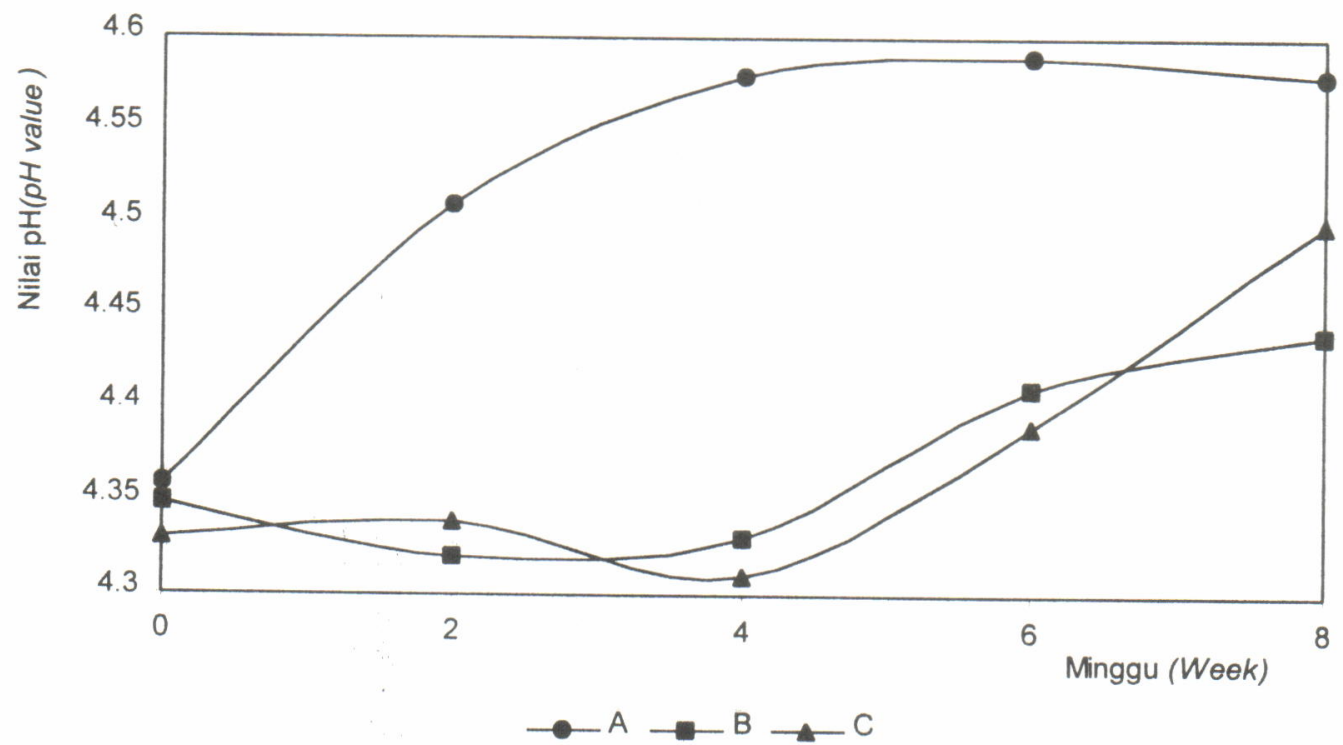

$A=$ Kontrol (Control)

$\mathrm{B}=$ Asinan kubis (Cabbage pickle)

$\mathrm{C}=$ Asinan sawi (Chinese leaf pickle)

Gambar 5. Perubahan nilai pH bekasam ikan sepat selama penyimpanan.

Figure 5. $\quad$ pH value of spotted gouramy bekasam during storage. 


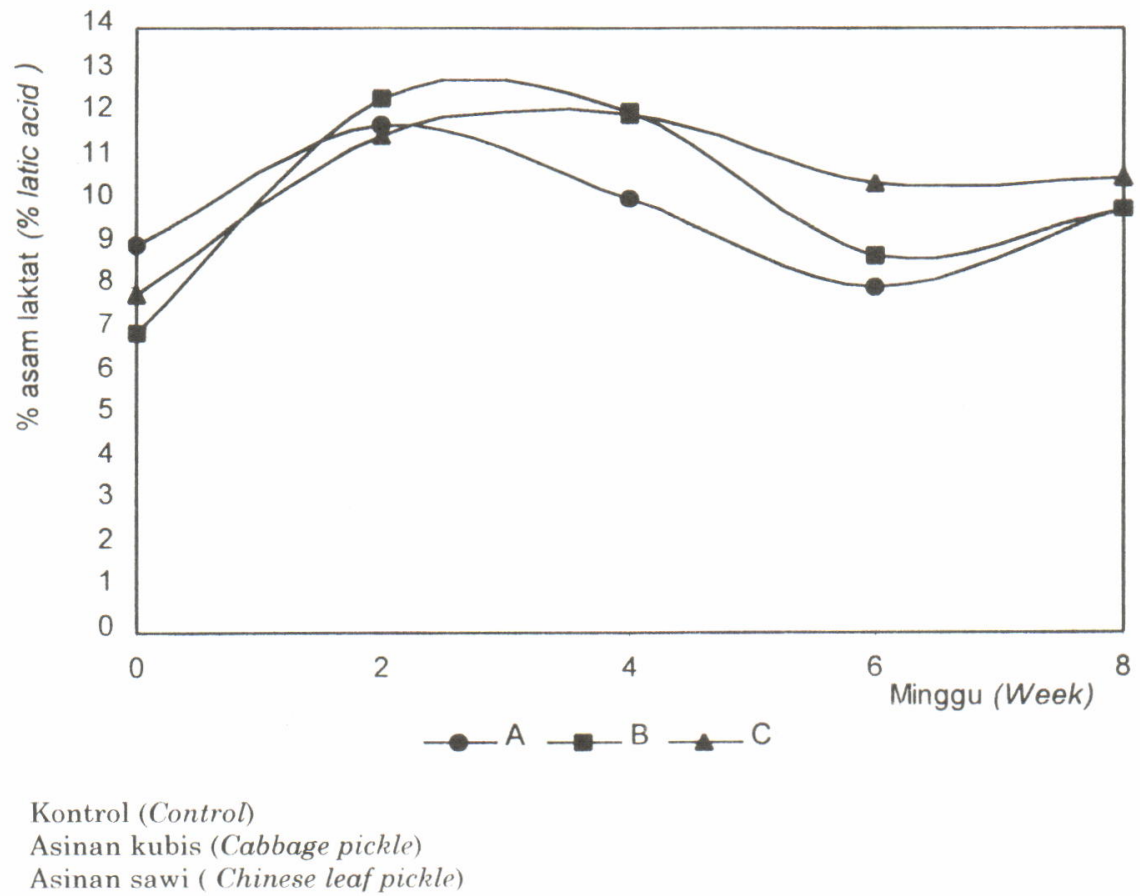

Gambar 6. Kadar asam laktat bekasam ikan sepat selama penyimpanan. Figure 6. Lactic acid content of spotted gouramy bekasam during storage.

Bila cairan tersebut ditambahkan ke daging ikan, mungkin menambah jumlah kandungan asam pada ikan, di samping selama fermentasinya juga menghasilkan berbagai macam asam, salah satunya adalah asam yang mudah menguap yang selama penyimpanan, produksi asam akan terus berlangsung. Hasil analisis ragam pada protein dan nitrogen bukan protein (NPN) untuk semua perlakuan tidak berpengaruh nyata, berarti tidak ada perubahan protein dan NPN selama penyimpanan. Perubahan protein dan NPN bekasam ikan sepat selama penyim lanan dapat dilihat pada Gambar 8 dan Gambar 9.

\section{- Hasil pengamatan organoleptik}

Rupa adalah kondisi fisik bagian luar tubuh ikan, yaitu antara lain keutuhan, kecerahan dan kerapian. Dari uji Kruskal-Wallis, dapat dilihat bahwa rupa bekasam tidak dipengaruhi oleh perlakuan, tetapi penyimpanan berpengaruh sangat nyata. Bekasam yang disukai panelis adalah yang disimpan selama 8 minggu.
Dari hasil uji Kruskal-Wallis pada warna dapat dilihat bahwa warna bekasam tidak dipengaruhi perlakuan, tetapi penyimpanan sangat berpengaruh nyata. Lama penyimpanan yang paling disukai konsumen adalah penyimpanan 0 minggu (setelah fermentasi tujuh hari). Keadaan ini disebabkan oleh bakteri asam laktat masih dalam pertumbuhan, rata-rata mencapai $10^{8}$ unit koloni/g. Kemungkinan banyaknya unit koloni bakteri asam laktat inilah yang menyebabkan warna bekasam masih cemerlang dan disukai oleh panelis (Irawadi, 1979). Bau dipengaruhi oleh perlakuan tetapi lama penyimpanan tidak berpengaruh nyata, sedangkan interaksinya berpengaruh nyata.

Dari hasil uji organoleptik terlihat bahwa rasa tidak dipengaruhi oleh semua perlakuan. Dari hasil uji Kruskal-Wallis menunjukkan bahwa tekstur tidak dipengaruhi oleh semua perlakuan. Tekstur erat hubungannya dengan kadar air, hal ini sesuai dengan stabilnya kadar air bekasam selama penyimpanan. 
Murtini, J.T.; Yuliana, E.; Nurjanah; dan Nasran, S.

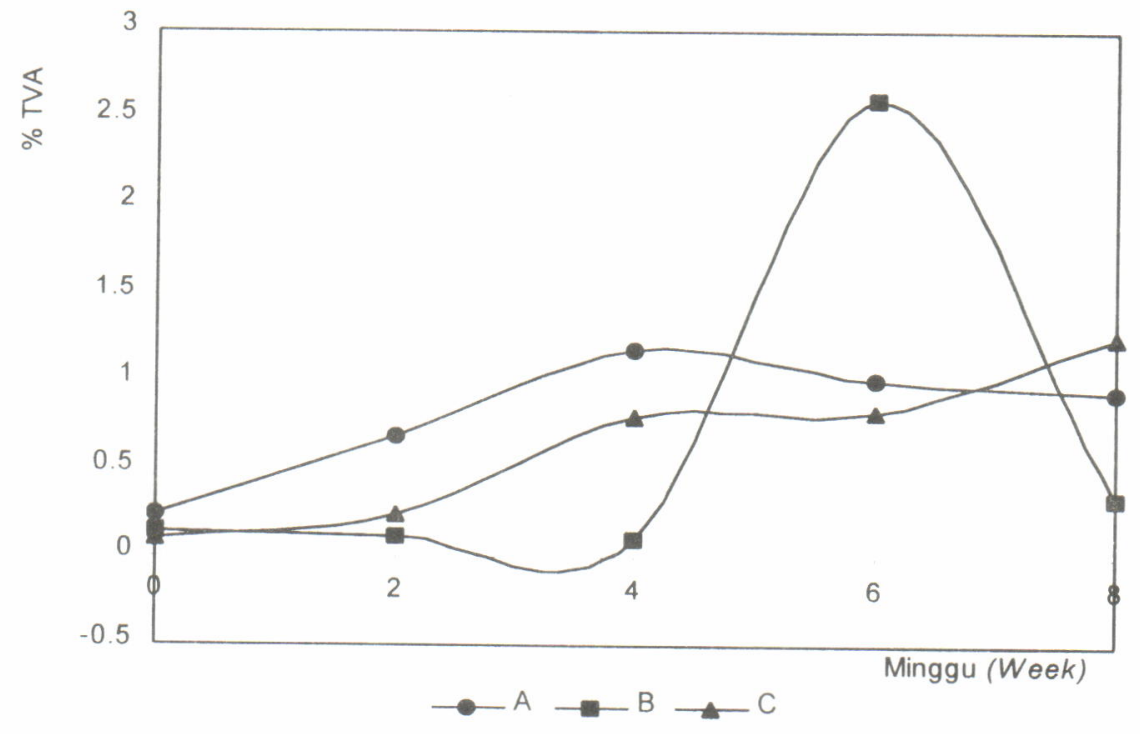

$\mathrm{A}=$ Kontrol (Control)
$\mathrm{B}=$ Asinan kubis (Cabbage pickle)
$\mathrm{C}=$ Asinan sawi (Chinese leaf pickle)

Gambar 7. Kadar TVA bekasam ikan sepat selama penyimpanan Figure 7. TVA content of spotted gouramy bekasam during storage

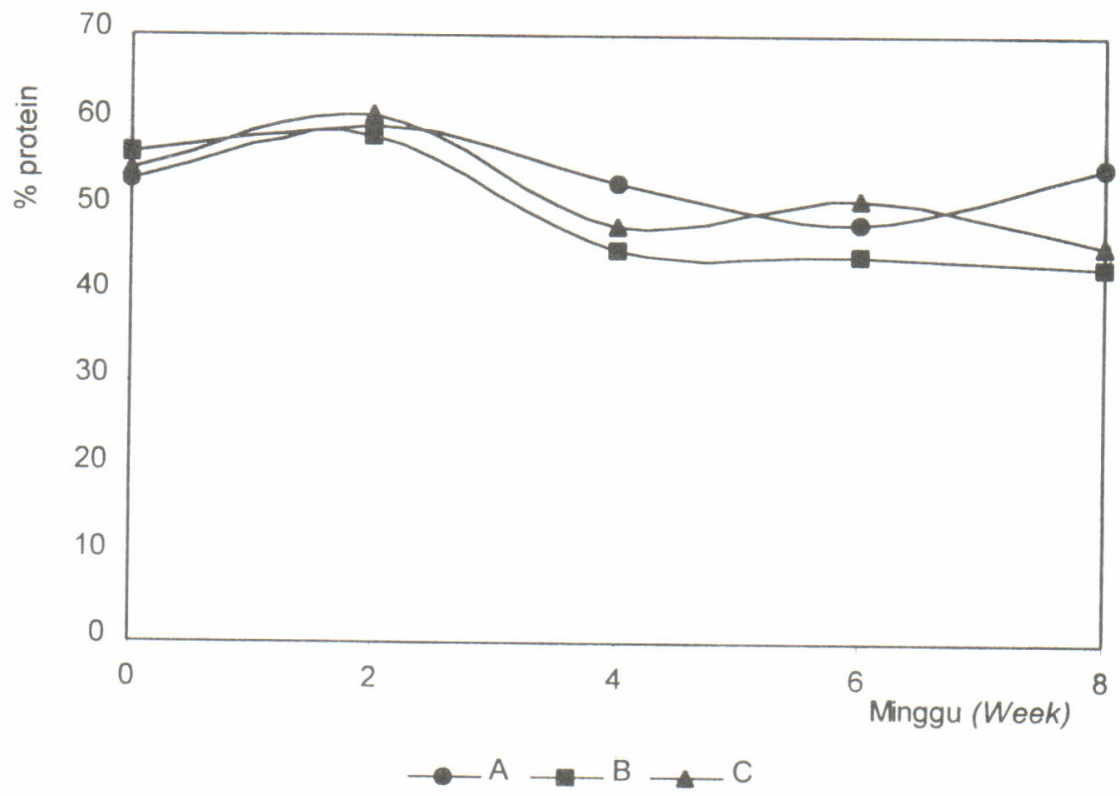

\footnotetext{
$\mathrm{A}=$ Kontrol $($ Control $)$

$\mathrm{B}=$ Asinan kubis (Cabbage pickle)

$\mathrm{C}=$ Asinan sawi (Chinese leaf pickle)
}

Gambar 8. Kadar protein bekasam ikan sepat selama penyimpanan.

Figure 8. Protein content of spotted gouramy bekasam during storage. 


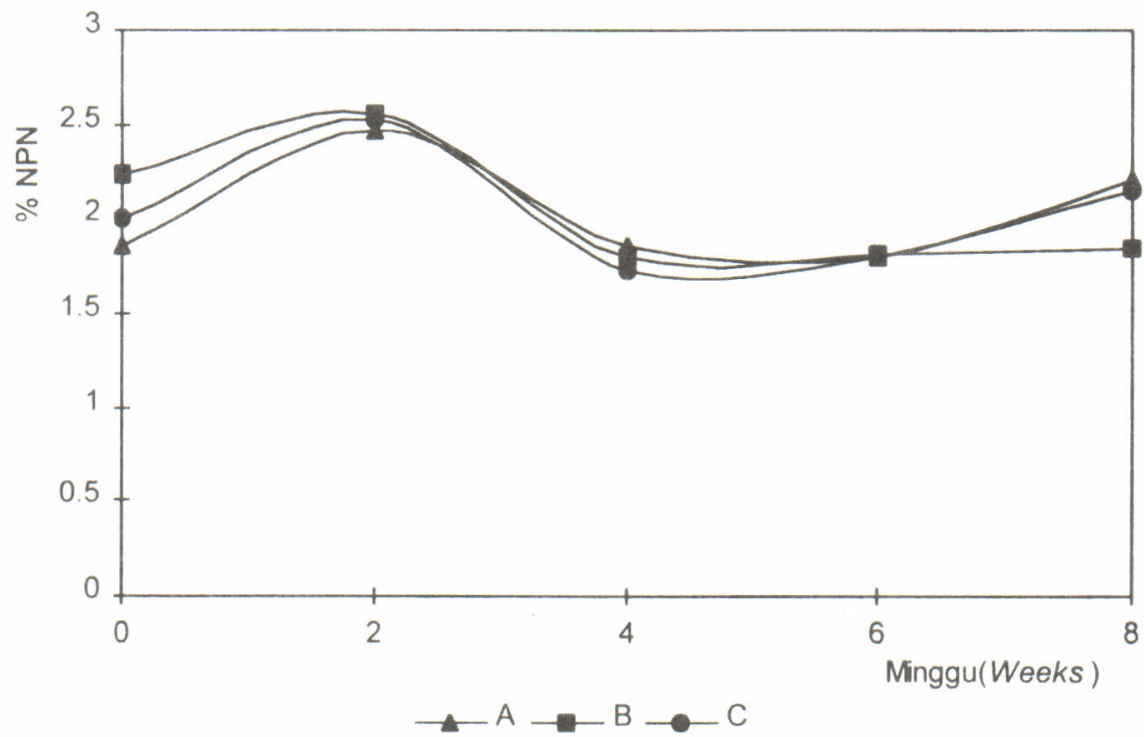

$\mathrm{A}=$ Kontrol (Control)
$\mathrm{B}=$ Asinan kubis (Cabbage pickle)
$\mathrm{C}=$ Asinan sawi (Chinese leaf pickle)

Gambar 9. Kadar NPN bekasam ikan sepat selama penyimpanan.

Figure 9. NPN content of spotted gouramy bekasam during storage.

\section{KESIMPULAN}

1. Perlakuan cairan asinan sawi dan kubis sebagai starter berpengaruh nyata terhadap jumlah koloni bakteri asam laktat, bakteri aerob, bakteri anaerob, dan khamir. Perlakuan tersebut juga berpengaruh terhadap nilai $\mathrm{pH}$, TVA dan lemak tetapi tidak mempengaruhi kadar asam laktat. Waktu penyimpanan berpengaruh terhadap semua parameter di atas. Dari hasil analisis mikrobiologi, bakteri anaerob sebagian besar adalah bakteri asam laktat.

2. Perlakuan cairan asinan sawi maupun asinan kubis dapat mencegah penurunan bakteri asam laktat maupun bakteri anaerob. Dalam hal ini perlakuan yang paling baik adalah cairan asinan sawi. Namun demikian cairan asinan sawi kurang baik, bila dilihat dari penghambatan pertumbuhan khamir.

3. Walaupun penambahan cairan asinan sawi maupun kubis tidak berpengaruh dalam hal warna, rasa, citarasa dan tekstur bekasam tetapi dapat memberikan bau produk yang paling disukai oleh panelis.

\section{DAFTAR PUSTAKA}

Adams, M.R.; R.D. Cooke; and P. Rattagol. 1985. Fermented fish product of South East Asia. Tropical Science Volume 25. Tropical Development and Research Institute. London.

AOAC. 1984. Official Methods of the Association of Official Analytical Chemist, $14^{\text {th }}$ ed. AOAC, Inc. Arlington, Virginia. 1018 p.

Blood, R.M. 1975. Lactic acid bacteria in marine herring. In Carr J.G., C.V. Cutting, and G.C. Whitting (ed.), Lactic Acid Bacteria in Beverage and Food. Academic Press, London, New York.

Fardiaz, S. 1985. Mikrobiologi Pangan. PAU Pangan dan Gizi IPB Bogor.

Garrega M.; M.Hugas; P.Gou; MT.Aymerich; J.Arnan; and J.M.Monfort. 1996. Technological and sensorial evaluation of Lactobacillus strains as starter cultures in fermented sausages. Int.J. Food Microbiology, 32. p.173-184. 
Irawadi, T.T. 1979. Pengaruh garam dan glukosa pada fermentasi asam laktat dari ikan kembung (Scomber neglectus). Thesis. Pasca Sarjana IPB. Bogor.

Leroi, F.; N.Arbey; J.Joffrand; and F.Chevalier. 1996. Effect of inoculation with lactic acid bacteria on extending the shelf-life of vacuum packed cold smoked. Int.J. Food Science and Technology, 31. p. 497-504.

Murtini, J.T.; F. Ariyani; A.M. Anggawati; dan S. Nasran. 1991. Pengolahan bekasam ikan mas (Cyprinus carpio). Jurnal Penelitian Pasca Panen Perikanan No.71. Balai Penelitian Perikanan Laut. p.11-23.

Murtini, J.T. 1992. Bekasam ikan mas. Kumpulan Hasil-hasil Penelitian Pasca Panen Perikanan.
Pusat Penelitian dan Pengembangan Perikanan. Jakarta. p. 135-139.

Nurwantoro. 1991. Pola pemecahan karbohidrat selama fermentasi tape ubi kayu dengan menggunakan inokulum murni kering. Thesis. Program Pasca Sarjana IPB. Bogor.

Prescott S.C. and C.G Dunn, 1959. Industrial Microbiology. McGraw-Hill Book Company, Inc.

Tanikawa, E. 1971. Marine Product in Japan. Koseisha-Koseikaku Company. Tokyo. p. 333-338.

Wood, B.J.B. and M.M. Hodge. 1985. Yeast-lactic acid bacteria interactions and their contribution to fermented food stuffs. In Wood,B.J.B. Microbiology of fermented foods. Vol 1. Elsevier Applied Science Publishers London and New York. 